Kong. Res. J. 3(2) : 75-78, 2016

ISSN 2349-2694

Kongunadu Arts and Science College, Coimbatore.

\title{
REPRODUCTIVE BIOLOGY OF GNETUM LATIFOLIUM BLUME (GNETALES) IN TAMIL NADU
}

\author{
Karupusamy, $\mathbf{S}^{*}$. \\ Department of Botany, Centre for Botanical Research, The Madura College (Autonomous), Madurai - 625011. \\ *Email: ksamytaxonomy@gmail.com
}

\begin{abstract}
The reproductive biology of Gnetum latifolium Blume studied in four different forest sites of Tamil Nadu. G. latifolium reported to have dioecious plants with less number male population in all the selected areas. Entamophilous cues observed with common anaemophily and pollinator may be flies. Pollination drops are also reported in young ovules. The seed maturation and germination frequency observed with very low frequency in all the selected population whereas in high number of abortive ovules reported in Western Ghats.
\end{abstract}

Keyword: Gentum latifolium, reproductive biology, seed maturation, germination.

\section{INTRODUCTION}

In Gymnosperms, Gnetales (Ephedra, Gnetum, Welwitschia) morphologically distinct true seeded plants and regularly produced bisexual cones and seeds usually with gynodioecious plants. This plant group has been long regarded as insect pollination due to its range-restricted distribution in tropical forests, where wind pollination is supposed to be detrimental. Several accounts reported that Gnetum and Ephedra produce bisexual cones with sterile or abortive ovules (Endress, 1996; Hufford, 1996). The genus Gnetum are woody climbers mostly in tropical Asia of about 40 species; only G. gnemon and $G$. costatum are free standing woody trees or shrubs and remaining species occur in mesic habitats. In Gnetum, functionally dioecious, male and female cones bear on different individuals. Until now many of the Gnetum species never been documented for their reproductive biology and nature of mechanism of dioicy. A few data are available on the internal structure of the male ovule in Gnetum (Vasil, 1959; Lata, 1950). Many authors noted reproductive biology of Gnetales and their implications for understanding of the evolution of higher plants (Hufford, 1996; Frohlich, 1999). Reproductive biology of many Gnetum species poorly understood (Endress, 1966).It is well known that many Angiosperms produce nectar as an attractant for pollinators, perhaps Gnetales reported that to produce pollination drops. The pollination drops may be produced from nucellus of the ovule and mainly functioned as pollen receptor on the female cone. But in Gnetales which may indicate a variation in the pollination syndrome especially in Ephedra has been reported exclusively entomophilic or in combination with anomophily (Meeuse et al., 1990; Niklas, 1992). The present study is aimed on the documentation of pollination mechanism and seed development in Gnetum latifoium.

\section{MATERIALS AND METHODS}

The study was conducted in different forest areas of Tamil Nadu such as Sirumalai hills (Dindigul district), Alagar hills (Madurai district), Megamalai hills (Theni district) and Tirunelveli hills (Tirunelveli district). The population survey was initially conducted and locates the population for reproductive biological studies from the year 2010 to 2015. The phonological events of all the selected population were keenly noted in each and every seasons starting from leaf flushing, leaf shedding, cone initiation, maturation, pollination, ovule development, seed production rate are tabulated form all the selected population in a $\mathrm{km}^{2}$ area.

\subsection{Pollination studies}

Selected male and female plants from each population noted for pollination studies. The plants were tagged with red threads and information slip tied permanently for observation of pollination events. The time of anther maturation and ovule maturation keenly observed with all the environmental events.To document potential pollinator (if any), eye observations of male and female cones with fully open stamens were conducted at randomly chosen plant of each population. Male and female cones of the individual observed in $30 \mathrm{~min}$ intervals. The activities of insects visiting the plants were assessed at a 1 - 5 scale, in which 1 indicates and inactive insect and 5 indicates a very active insect. The insects were photographed, 
captured in $70 \%$ ethanol and brought to lab for identification.

\subsection{Pollen studies}

To investigate Gnetum pollen was present in the air near the plants, pollen traps consisting of microscopic slides covered with vaseline were placed on pole on one meter above the ground in each direction distances such as $1 \mathrm{~m}, 5 \mathrm{~m}, 10,15 \mathrm{~m}$ and $20 \mathrm{~m}$ for 3 days. During those days, the weather was dry, sunny and windy and the stamens of the male plants were fully open. The slides of the pollen traps were replaced every evening covered with an additional microscopic slide for observation. The slides were transferred to laboratory, observed with compound microscope at 40X enlargement.

\section{RESULTS AND DISCUSSION}

Gnetum latifolium is an uncommon Gymnosperm sporadically distributed in Tamil Nadu especially in tropical moist deciduous forests of Western Ghats and Eastern Ghats. It is a climbing species with broad leaves and its population located four different forest sites for study purposes. The reproductive characters with pehnological events of four population sites were observed and tabulated (Table 1). The maximum number of individuals observed from Sirumalai hills $\left(76 / \mathrm{km}^{2}\right)$ followed by Alagar hills (51/ $\mathrm{km}^{2}$ ), Megamalai hills (47/ $\mathrm{km}^{2}$ ) and Tirunelveli hills $\left(16 / \mathrm{km}^{2}\right)$. All these populations have low frequency of male plants which is about
1:15 ratio of male and female plants.Male cone initiation in the month of April in Sirumalai hills and Alagar hills whereas in Megamalai hills and Tirunelveli hills the male cone started produce in the month of June and July. The average pollen density observed in 5- $20 \mathrm{~m}$ radius of the male plant of each population showed maximum in Sirumalai hills (15) followed by Megamalai hills (12), Tirunelveli hills (10) and Alagar hills (9).

Period of female cone initiationshowed in the month of May in Sirumalai and Alagar hills, but in Megamalai and Tirunelveli hills it was started in the month of July. It shows well-marked difference in the phonological events of cone formation in Western Ghats and Eastern Ghats. The protandry is noted in the all populations of $G$. latifolium in Tamil Nadu. The average ovule ratio on female cone is calculated in each population, it showed higher number in Sirumalai hills (40/cone), followed by Alagar hills (38/cone), Tirunelveli hills (21/cone) and Megamalai hills (12/cone). In Megamalai population the higher range of abortive ovules observed on the female cone (Fig. 1h). Seed maturation was noted in the month of August in Eastern Ghats and September in Western Ghats respectively. Habitat seed germination frequency is very low in all the selected population sites, usually germination take place in the month of November in Eastern Ghats and January in Western Ghats (Table 1). The different reproductive stages of Gnetum latifolium is given in Fig.1.

Table 1. Reproductive characters of Gnetum latifolium observed from the four different populations in Tamil Nadu.

\begin{tabular}{|c|c|c|c|c|c|}
\hline \multirow[b]{2}{*}{ Characters } & & \multicolumn{4}{|c|}{ Gnetum latifolium population sites } \\
\hline & & $\begin{array}{l}\text { Sirumalai } \\
\text { hills }\end{array}$ & Alagar hills & $\begin{array}{l}\text { Megamalai } \\
\text { hills }\end{array}$ & $\begin{array}{l}\text { Tirunelveli } \\
\text { hills }\end{array}$ \\
\hline $\begin{array}{l}\text { Number of mature individuals } \\
\mathrm{km}^{2}\end{array}$ & / & $\begin{array}{l}76 \text { (2 male; } 74 \\
\text { female) }\end{array}$ & $\begin{array}{l}51 \text { (6 male; } 45 \\
\text { female) }\end{array}$ & $\begin{array}{l}47 \text { (2 male; } 45 \\
\text { female) }\end{array}$ & $\begin{array}{c}16 \text { (3 male; } 13 \\
\text { female) }\end{array}$ \\
\hline Number of seedlings & & 12 & 6 & 15 & 3 \\
\hline Period of male cone formation & & April - May & April - May & June - July & July - August \\
\hline $\begin{array}{l}\text { Average pollen density } \\
\text { microscopic field at } 40 X(\geq 20 \\
\text { radius) }\end{array}$ & in & 15 & 9 & 12 & 10 \\
\hline Period of female cone formation & & May - July & May - July & July - August & July - August \\
\hline $\begin{array}{l}\text { Average ovule ratio per female } \\
\text { cone }\end{array}$ & & 40 & 38 & 12 & 21 \\
\hline Seed maturation & & August & August & September & September \\
\hline Seed germination & & November & November & January & January \\
\hline
\end{tabular}



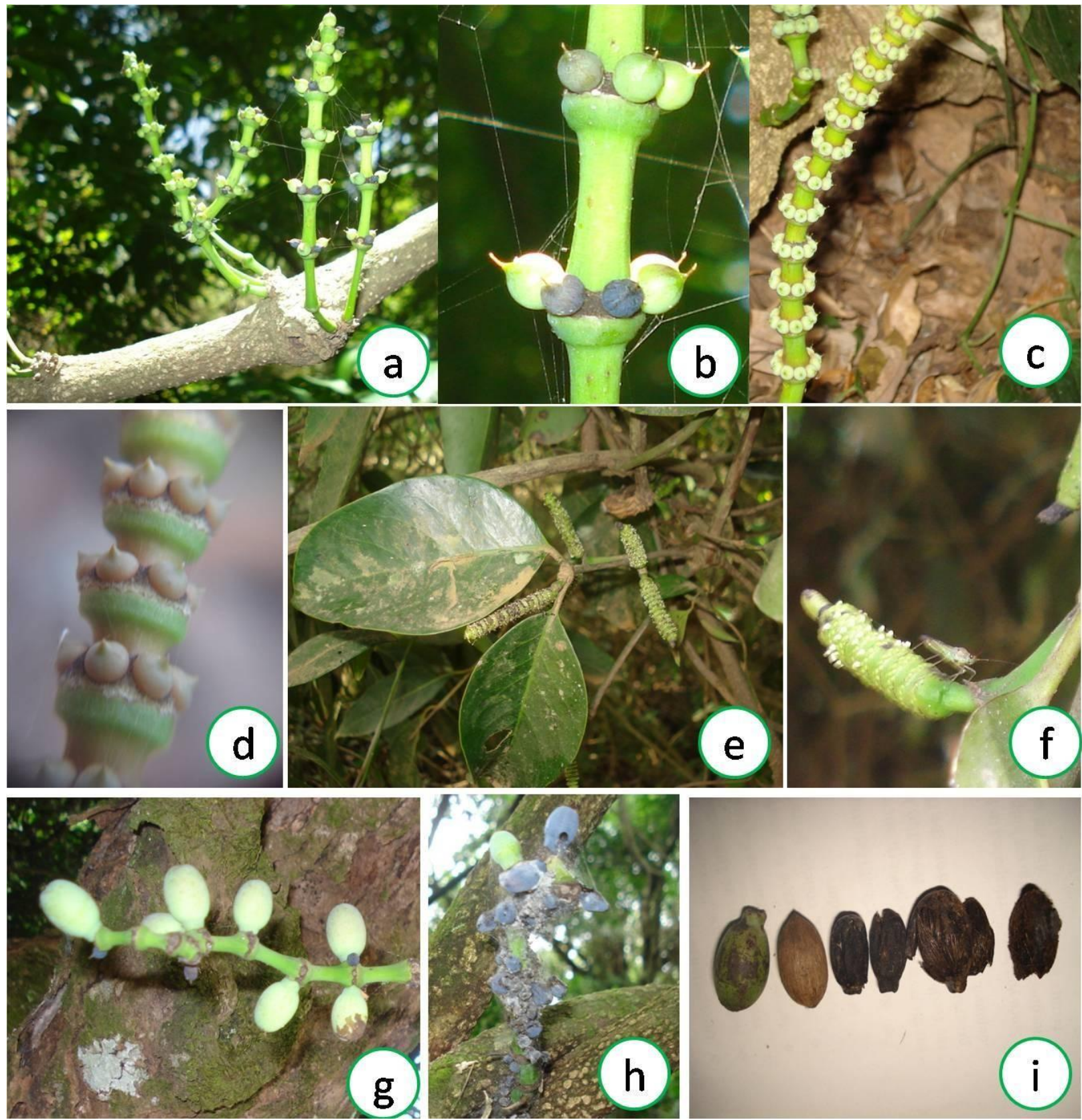

Fig. 1. Gnetum latifolium - Reproductive stages.

a) A bunch of female cones on stem; b) Female cone enlarged with elongated papilla on ovules; c) 20 days mature ovules; d) 20 mature ovules enlarged with cupuels; e) Male cones on leafy twig; f) insects sporting on male cone; f) 60 days mature seeds; h) infected female cone; i) different stages of seeds from mature to decomposed wall layers.

There was no report on quantitative distributional account of Gnetales in India or elsewhere in Asia. Usually Gentum population have less number of male plants and predominant population of female plants. Pollination drops usually produced in Gnetales from nucellar secretion in young ovules (Haycraft and Carmichael, 2001). G. latifolium is found to have unisexual cones in dioecious plants but in G.gnemon reported bisexual cones with male ovule. In recent report accounted the role of bisexual cones with sterile ovules in the breeding system of Gnetales remains unclear. Though in $G$. latifolium cones are unisexual, pollination droplets produced even in sterile ovules with rich content of sugars attracts fly pollinators. Similar pollination droplets were reported in $G$. 
gnemon (Kato et al., 1996). Sterile ovules reported in G. cuspidatum, G. microcarpum, G. diminutum and $G$. loerzingii which are all African species and their ovules hidden among the hairs in cupules. There are no true nectarines found those species (Jorgensen and Catarina, 2015). In several Gnetum species of their pollination drops noted mistakenly as nectar. However, African species of Gnetum have unisexual male cones similar to G. latifolium. Seed germination studies are also not available for any Gnetum species, usually it take place year around to germinate the seeds due to hard and fibrous seed coats. The present report is given the base line data for conservation of the species and also the study impressed the seed germination studies needed for these ancestral plant species.

\section{REFERENCES}

Carmichel, J.S., and W.E. Friedman, (1995) Double fertilization in Gnetum gnemon: The relationship between the cell cycle and sexual reproduction. The Plant Cell 7: 1975-1978.

Endress, P. K. (1996) Structure and function of female and bisexual organ complexes in Gnetales. Internat. J. Plant Sci. 157: S113-S125.

Frohlich, M. W. (1999) MADS about gnetales. Proceedings of the National Academy of Sciences, USA 96: 8811-8813.

Haycraft, C.J., and J.S. Carmichael., (2001) Development of sterile ovule on bisexual cones of Gnetum gnemon (Gnetaceae). American J. Botany 88: 1326-1330.
Hufford, L. (1996) The morphology and evolution of male reproductive structures of Gnetales. Internat. J. Plant Sci.157: S95-S112.

Jorgensen, A., Catarina, R. (2015) Reproductive morphology in the Gnetum cuspidatum group (Gnetales) and its implications for pollination biology in the Gnetales. Plant Ecology Evolut. 148: 387-396.

Kato, M., T., Inoue andT. Nagamistu, (1995) Pollination biology of Gnetum (Gnetaceae) in a lowland mixed dipterocarp forest in Sarawak. American J. Botany 82: 862-868.

Lata, M. (1960) Morphology and embryology of Gnetum gnemon L. Part 1.Ph.D. dissertation, University of Delhi, Delhi, India.

Momose, K., T., Yumoto, T., Nagamitsu, M., Kato, H., Nagamasu, S., Sakai, R.D., Harrison, T., Itioka, A.A., Hamid andT.Inoue (1998) Pollination biology in a lowland Dipterocarp forest in Sarawak, Malaysia I. Characteristics of the plant-pollinator community in a lowland Dipterocarp forest. American J. Botany 85: 1477-1501.

Vasil, V. (1959) Morphology and embryology of Gnetum ula Brongns. Phytomorphol.9: 167-215.

Yan-Bing, G., M., Yang, J.C., Vamosi, Y., Hong-Mei, M., Wei-Xue, L., Jiao-Kun, W.Tao, (2015) Wind or insect pollination? Ambophily in a subtropical Gymnosperm Gnetum parvifolium (Gnetales). Plants Species Biol,; DOI: 10.111/1442-198412112. 